\title{
СУЧАСНИЙ СТАН ТА ПЕРСПЕКТИВИ ВИРОБНИЦТВА БІОНАФТИ МЕТОДОМ ШВИДКОГО ПІРОЛІЗУ 3 ЛІГНОЦЕЛЮЛОЗНОЇ БІОМАСИ
}

\author{
Г.Г. Дідківська, канд. техн. наук, 3.В. Маслюкова, С.Г. Новицька \\ Інститут відновлюваної енергетики НАН України, \\ 02094, вул. Гната Хоткевича 20А, м. Київ, Україна.
}

Стаття присвячена питанням сучасного стану отримання екологічно чистого рідкого біопалива (біонафти) 3 лігноцелюлозної біомаси шляхом ї̈ термохімічної конверсії, а також перспективам розвитку иього напрямку найближчим часом. В даний час термохімічна конверсія (швидкий піроліз) рослинної біомаси, яка містить в своєму складі велику кількість лігночелюлози, в рідке біопаливо, є одним з напрямів залучення нетрадиційних джерел енергї̈ в енергобаланс Украӥни. У зв'язку з ичм необхідно оцінити сучасний стан розвитку промислового отримання рідкого біопалива 3 лігноцелюлози рослинної біомаси і подальші перспективи в цій галузі біоенергетики. Для цієї мети на основі вивчення наукової бібліографії, яка торкається проблеми виробництва рідкого біопалива, проаналізовано вже наявний досвід різних країн щзодо промислового виробництва біодизельного пального методом швидкого піролізу $і$ показана можливість використання лігноцелюлозної біомаси в якості сировини для його отримання. Так само наводяться відомості щодо технологій, які вийшли на промисловий рівень. Встановлено, що технологія отримання біопалива з лігноцелюлозної біомаси має широке поширення в багатьох країнах світу. В роботі наводиться опис технологічної схеми швидкого піролізу деревини та його основних етапів. Показано, щьо під час використання технології термохімічної конверсії лігноцелюлозної біомаси можна отримувати високоякісний вуглеводневий продукт - біонафту, і дається опис основних переваг иього продукту. В результаті роботи встановлено, що технологія виробництва біонафти з лігноцелюлозної біомаси методом швидкого піролізу має широкі перспективи для подальиого розвитку.

Результати, отримані авторами статті, можуть бути використані у подальшому вивченні питань, пов'язаних 3 термохімічною конверсією біомаси в рідке біопаливо. Бібл. 12.

Ключові слова: лігноцелюлозна біомаса, швидкий піроліз, біонафта, термохімічна конверсія, рідке біопаливо, абляиійний піроліз.

\section{CURRENT STATE AND PROSPECTS FOR PRODUCING OF BIO-OIL FROM LIGNOCELLULOSIC BIOMASS BY FAST PYROLYSIS METHOD}

\author{
H. Didkivska, candidate of technical science, Z. Masliukova, E. Novitska \\ Institute of Renewable Energy of the National Academy of Sciences of Ukraine, \\ 02094, 20A Hnata Khotkevycha St., Kyiv, Ukraine.
}

The article is devoted to the issues of the current state of obtaining environmentally friendly liquid biofuel (bio-oil) from lignocellulosic biomass by its thermochemical conversion, as well as the prospects for the development of this direction in the near future. At present, thermochemical conversion of plant biomass (fast pyrolysis), which contains a large amount of lignocellulose, into liquid biofuel is one of the developing directions for involving unconventional energy sources into the energy balance of Ukraine. In this regard, it is of interest to assess the current state of the development of industrial production of liquid biofuel from plant biomass lignocellulose and further prospects in this branch of bioenergy. For this purpose, based on the study of scientific bibliography concerning the problem of liquid biofuel production, the existing experience of various countries in the industrial production of biodiesel fuel by the fast pyrolysis method is analyzed and the possibility of using lignocellulosic biomass as a raw material for its production is shown. It also provides information on technologies that have reached the industrial level. It has been established that the technology for producing biofuel from lignocellulosic biomass is widespread in many countries of the world. The paper describes the technological scheme of fast pyrolysis of wood and the main stages of production. It is shown that using the technology of thermochemical conversion of lignocellulosic biomass, it is possible to obtain a high-quality hydrocarbon product - bio-oil, and a description of the main advantages of this product is given. As a result of the work, it was established that the technology of bio-oil production from lignocellulosic biomass by the method of fast pyrolysis has broad prospects for further development.

The results obtained by the authors of the article can be used in the further study of issues related to the thermochemical conversion of biomass into liquid biofuel. Ref. 12.

Keywords: lignocellulosic biomass, fast pyrolysis, bio-oil, thermochemical conversion, liquid biofuel, ablative pyrolysis. 


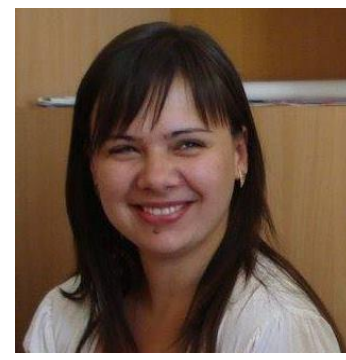

Г.Г. Дідківська H. Didkivska

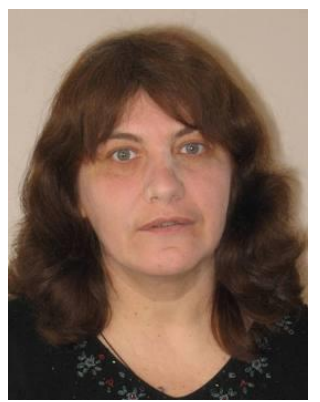

3.В. Маслюкова

Z. Masliukova

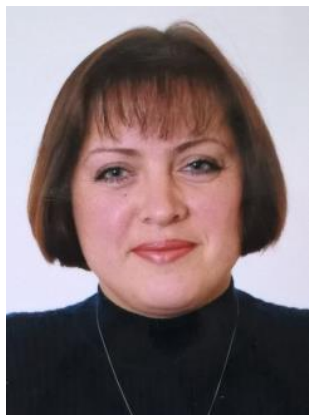

С.Г. Новииька

E. Novytska
Відомості про автора: канд. техн. наук, науковий співробітник відділу відновлюваних органічних енергоносіїв IBE НАН України.

Освіта: Вища. Національний авіаційний університет.

Наукова сфера: біогаз, переробка органічних відходів.

Публікації: 30 .

ORCID: 0000-0002-8314-9606

Контакти: тел/факс: +38(044)206-28-09 e-mail: biomassa@ukr.net

Відомості про автора: науковий співробітник відділу відновлюваних органічних енергоносіїв IBE НАН України.

Освіта: Вища. Київський Державний університет, факультет гідрогеології та інженерної геології.

Наукова сфера: біогаз, переробка органічних відходів.

Публікації: 62 .

ORCID: 0000-0002-4180-7930

Контакти: тел/факс: +38(044)206-28-09

e-mail: biomassa@ukr.net

Відомості про автора: науковий співробітник відділу відновлюваних органічних енергоносіїв IBE НАН України.

Освіта: Вища. Одеський інженернобудівельний інститут, факультет теплогазопостачання та вентиляції. Наукова сфера: піроліз біомаси. Публікації: 41.

ORCID: 0000-0001-9217-4099

Контакти: тел/факс: +38(044)206-28-09 e-mail: biomassa@ukr.net
Author information: candidate of technical science, researcher of the Department of Renewable Organic Energy Carriers IRE NAS of Ukraine.

Education: National Aviation University, 2002.

Research area: biogas, organic waste utilization.

Publications: 30 .

ORCID: 0000-0002-8314-9606

Contacts: tel./fax: +38(044)206-28-09

e-mail: biomassa@ukr.net

Author information: Institute of Renewable Energy of NAS of

Ukraine, researcher.

Education: Kyiv National University, Faculty of Hydrology and Engineering Geology.

Research area: biogas, organic waste utilization.

Publications: 62

ORCID: 0000-0002-4180-7930

Contacts: tel./fax: +38(044)206-28-09

e-mail: biomassa@ukr.net

Author information: Institute of Renewable Energy of NAS of Ukraine, researcher.

Education: Odessa Engineering and Construction Institute, Faculty of Heat and Gas Supply and Ventilation.

Research area: pyrolysis of biomass.

Publications: 41.

ORCID: 0000-0001-9217-4099.

Contacts: tel./fax:+38(044)206-28-09

e-mail: biomassa@ukr.net

Перелік використаних позначень та скорочень:

КС - киплячий шар;

ЦКШ - циркулюючий киплячий шар.

Вступ. У зв'язку з постійно зростаючим в світі та Україні дефіцитом традиційних видів палив i нестабільністю цін на них, а також зміною кліматичних умов, що викликані їх використанням, виникає необхідність пошуку альтернативних джерел енергії, здатних замінити викопні паливні ресурси. Одним з таких джерел $\epsilon$ рослинна біомаса, 3 якої можливо виробляти біодизельне паливо.

Майже $\quad 90 \%$ світового виробництва біодизельного палива припадає на країни ЄС. У цих країнах 3 метою забезпечення швидких темпів виробництва, виробникам біопалива надається державна підтримка у вигляді високих тарифів на цей вид палива, масштабних державних субсидій, а також встановлення високих тарифів на імпорт етанолу.

Україна має хороші передумови для майбутнього розвитку відновлюваних джерел енергії та, зокрема, біоенергетики. Країна має великий потенціал низькоякісної біомаси (відходи сільського і комунального господарства, деревні відходи та ін.), доступний для виробництва енергії, але він широко не використовується через недостатній розвиток i застосування технологій 3 iï утилізації. 
Наприклад, за даними доктора економічних наук, директора Європейського аналітичного центру В. Голяна обсяг тільки деревних відходів в 2016 році склав 933,8 тис. тонн, обсяг спалених деревних відходів - 381,5 тис. тонн, а утилізованих деревних відходів - 58,3 тис. тонн. Проблема поводження 3 відходами $€$ центральною в питанні формування сучасної екологічної політики. Необхідним пріоритетом реформ децентралізації влади і органів місцевого самоврядування повинно стати створення більш сприятливого інвестиційного клімату в цій сфері.

В умовах обмежених можливостей центральних і регіональних, фінансових фондів і бюджетів територіальних громад першочергове значення набуває залучення до реалізації проєктів модернізації індустрії поводження 3 відходами приватного бізнесу, в тому числі зарубіжних підприємницьких структур, урядів іноземних держав та міжнародних фінансовокредитних організацій. Формування сучасної індустріальної бази поводження з відходами має бути не тільки важливою складовою державної та регіональної екологічної політики, а й одним із пріоритетів децентралізації влади та реформи місцевого самоврядування, а також створення привабливої законодавчої бази для збільшення обсягів інвестицій.

У цій роботі розглядається один із напрямів заміни викопного нафтового палива на альтернативне рідке біопаливо (біонафти), яке можна отримувати 3 компонентів лігноцелюлозної біомаси. Це технологія швидкого піролізу. В даний час технологія отримання рідкого біопалива методом швидкого піролізу має особливий інтерес, оскільки рідкі продукти піролізу $\epsilon$ найбільш цінними продуктами завдяки зручності зберігання, транспортування та універсальності їх застосування в двигунах внутрішнього згоряння, котлах, турбінах і т.д.

Виробництво рідкого палива 3 лігноцелюлози біомаси, яке може заміщати нафту в різних варіантах, є основною метою швидкого піролізу. У цьому полягає його завдання на відміну від повільного піролізу, який застосовується для виробництва біовугілля. Технологія швидкого піролізу має низку переваг над повільним піролізом, які полягають в можливості управління робочими режимами піролізу; збільшенні терміну служби обладнання, i, так само в зниженні енергоємності технологічного процесу. Крім основного рідкого продукту, в процесі швидкого піролізу утворюються й побічні продукти, такі як газ i напівкокс. Під час реакції швидкого піролізу практично відсутні теплові втрати, що пов'язано 3 використанням побічних продуктів для забезпечення підведення тепла до піролізного реактора [1].

За кордоном фундаментальними i прикладними дослідженнями технології швидкого піролізу біомаси понад 20 років займається Центр технічних досліджень (Фінляндія). Провідні дослідження в області швидкого піролізу біомаси проводяться такими країнами як Канада, США, Греція, Німеччина, Португалія, Голландія, Іспанія, Великобританія, Малайзія та ін. [2].

У країнах дальнього та ближнього зарубіжжя питанням виробництва рідкого біопалива 3 рослинної біомаси приділяли значну увагу в своїх наукових дослідженнях такі вчені як Бріджуотер А., Хоекстра Е., Леде Дж., Поллекс А., Джендуби Н., Вендербош Р., Браун Дж., а так само М.I. Богданович, B.М. Башкіров, А.М. Грачов, А.М. Кислицин та ін. В Україні значний внесок в дослідження піролізу біомаси внесли вітчизняні вчені: В.М. Клименко, О.І. Баштовий, Є.Т. Базєєв, М.В. Губинський, В.Г. Носач, Т.О. Антощук, В.І. Зубенко та ін.

Подальші перспективи застосування технології швидкого піролізу відходів лігнецеллюлозной біомаси - перший крок на шляху до відмови від викопного палива у виробництві тепла та внесок в пом'якшення кліматичних змін на планеті. У майбутньому можлива подальша переробка біонафти в продукти 3 більш високою доданою вартістю (напр., автомобільне паливо).

Постановка завдання. Мета роботи полягає в оцінці перспективи виробництва 3 лігноцелюлози рослинної біомаси екологічно чистого рідкого біопалива (біонафти) за допомогою технології швидкого піролізу, а також в оцінці можливості застосування цієї технології в Україні 3 метою часткового або повного заміщення імпортованої нафти. Результати роботи можуть бути запропоновані для ознайомлення інвесторам і зацікавленим особам в галузі біоенергетики. Методи досліджень 
полягають в огляді, аналізі, систематизації та узагальненні наукових праць зарубіжних i вітчизняних авторів.

\section{Виклад}

основного

матеріалу.

Лігноцелюлозна біомаса - це біомаса рослинного походження, в якості якої можуть використовуватися як сільськогосподарські відходи, так і відходи лісового господарства. Сюди ж відноситься й енергетична деревна сировина. У складі рослинної клітини лігноцелюлозної біомаси містяться три біополімера: целюлоза (33-60\%), геміцелюлоза (6-30\%) і лігнін (9-30\%) [3].

Під час термохімічної переробки лігноцелюлозної біомаси утворюється рідке паливо - біонафта (конденсована частина парогазової суміші), що $є$ маслянистою, в'язкою рідиною темного кольору, теплотворна здатність якої знаходиться в інтервалі 15-20 Дж / кг [4]. Згідно з роботою [5], в лабораторних установках вихід біонафти з сухої біомаси може становити до $65 \%$.

За даними фінської енергетичної компанії Fortum, перехід 3 викопних, видів палива на біонафту може скоротити викиди вуглекислого газу більш ніж на 90\%, що сприятливо позначиться на якості повітря. Виробництво біонафти до 50000 тонн на рік, чого вистачить для опалення 10000 окремих будинків або 24000 квартир середньої площі, може призвести до скорочення викидів $\mathrm{CO}_{2}$ приблизно на 60000 тонн на рік, а скорочення викидів діоксиду сірки - приблизно на 320 тонн на рік. Це пов'язано 3 тим, що біонафта $\epsilon$ екологічно чистим біопаливом, в продуктах згоряння якого відсутні канцерогенні сполуки. Це підтверджують в своїх дослідженнях такі вчені, як Гелетуха Г.Г. і Желєзна Т.А., які в роботі [6] провели порівняння характеристик хімічного складу біонафти, отриманої при швидкому піролізі деревини 3 традиційними рідкими паливами (дизельне паливо і мазут). Як показано в цій роботі, в хімічному складі біонафти практично відсутня сірка, тоді як в дизельному паливі вона коливається в інтервалі $0,15-0,30 \%$, а в мазуті становить вже $2 \%$. Відсутність сірчистих сполук в паливі позитивно позначається на роботі вихлопної системи та її корозійної стійкості. Що стосується азоту, то за даними роботи [4] його зміст дуже незначний та становить до $0,2 \%$. Таким чином, використання біонафти в якості альтернативного палива покращує екологічну ситуацію й допомагає реалізувати програму Кіотського протоколу про скорочення парникових викидів.

Біонафта має високу енергетичну щільність $\left(28\right.$ ГДж/ $\left.{ }^{3}\right)$ [6]. За цим показником вона поступається лише дизельному паливу, енергетична щільність якого становить 36 ГДж / м³. У цьому полягає перевага біонафти в порівнянні з вихідною біомасою.

Основною особливістю швидкого піролізу $\epsilon$ дуже висока швидкість нагрівання сировини (кілька тисяч градусів на секунду) і швидке охолодження i конденсація одержуваних продуктів у вигляді пари і газу (1-2 сек.). При тиску 100 кПа за період процесу в 1-2 секунди можливе отримання рідини до $75 \%$ [7].

Технологічна схема швидкого піролізу деревини містить такі етапи: подрібнення деревини; висушування подрібненої деревини; піроліз; охолодження і стабілізація вугілля; конденсація парів летких продуктів або аерозолю, у вигляді якого існує продукт піролізу, 3 метою отримання рідини.

Подрібнення деревини. Подрібнення деревини необхідне для зменшення часу прогріву частинок біомаси, оскільки чим менший їхній розмір, тим швидше вони прогріваються, тобто існуе пряма залежність між розміром частки біомаси й часом ii перебування в піролізному реакторі.

Висушування деревини. Висушування деревини відбувається при температурі 130$155^{\circ} \mathrm{C}$ до вологості $15 \%$. При цьому підвищується теплотворна здатність кінцевого продукту.

Піроліз. На етапі піролізу відбувається перехід сировини з твердої фази в пароподібний $\mathrm{i}$ газоподібний агрегатні стани.

Охолодження $і$ стабілізація вугілля. На цьому етапі відбувається поділ пароподібних продуктів на біонафту та піролізний газ [2].

Конденсаиія парів летких продуктів. На великих установках для конденсації парів летких продуктів зазвичай використовується контакт 3 захололою піролізною рідиною. Цей спосіб дуже ефективний, але щоб уникнути забивання устаткування важкими елементами, що конденсуються, потрібний ретельний підбір механізмів і конструкції системи. 
На даний час, найпоширеніші технології швидкого піролізу за конструкційними особливостями реактора можна поділити на такі типи: піроліз в киплячому шарі (КС); піроліз в циркулюючому киплячому шарі (ЦКШ); абляційний піроліз; піроліз в циклонних реакторах; піроліз в реакторі 3 двома шнеками; вакуумний піроліз. Вони відрізняються способами теплопередачі часткам біомаси (конвективна i кондуктивна теплопередача), продуктивністю реактора, розмірами вихідної сировини й іншими характеристиками. За оцінками Міжнародного енергетичного агентства отримання біопалива за технологією абляційного піролізу $\epsilon$ найбільш економічно вигідним способом [8].

Технологія виробництва біонафти методом швидкого піролізу має широкі перспективи розвитку. Підтвердженням цього $\epsilon$ великий спектр використання даного продукту. В даний час існує близько 20 варіантів комерційного застосування біонафти [9]. Найбільш простим i перспективним способом використання біонафти $\epsilon$ використання ii в якості котельного палива. Роботи в цій галузі ведуться за двома напрямками. Перший напрямок полягає в адаптації систем спалювання до біонафти. Другій - в удосконаленні самої технології швидкого піролізу й отриманні більш якісного рідкого продукту.

Біонафта також може бути використана як: альтернативне паливо; сировина для виробництва технічного вуглецю; зв язуюче для композитних матеріалів; сировина для дорожнього будівництва; сировина для хімічної промисловості [10]. За кордоном біонафта успішно застосовується в якості котельного палива як альтернатива мазуту. Так само біонафта використовується в ряді проектів для вироблення електроенергії в дизельних $\mathrm{i}$ газотурбінних двигунах. Біонафта використовується в різних країнах в різних варіантах. Наприклад, в Швеції і Фінляндії біонафта використовується як замінник котельного палива, а в Данії, Італії, Фінляндії та Великобританії - для когенераційного виробництва теплоти та електроенергії на дизельних електростанціях [6].

У Казанському національному дослідному технологічному університеті (Республіка
Татарстан) розроблена установка швидкого піролізу біомаси, що діє в безупинному режимі 3 продуктивністю приблизно чотири тисячі тонн сухої сировини в рік. Установка призначена для переробки лігноцелюлозних відходів невеликих підприємств. Основними продуктами швидкого піролізу відходів підприємств $є$ біонафта i біовугілля. Крім того, виробляється піролізний газ, який спалюється в енергетичному модулі комплексу. Вихід рідких продуктів становить $56 \%$, вихід вугілля - близько 20\%. Важливими конкурентними перевагами розробленої технології є мобільність, автономність, 100відсоткова утилізація відходів, можливість переробки великих частинок біомаси та отримання в результаті комерційного продукту [11].

В Інституті енергетики Національної академії наук Білорусі розроблений $\mathrm{i}$ виготовлений експериментальний стенд отримання рідких продуктів піролізу шляхом термохімічної конверсії деревної біомаси. В якості сировини використовувалася соснова тріска із середнім розміром фракції 45 мм. Рідкі продукти піролізу збиралися в бакунакопичувачі. Були визначені основні характеристики отриманих продуктів. Виміряне значення в'язкості при температурі $17,1{ }^{\circ} \mathrm{C}$. в середньому склало 0,4 Па · c. Температура спалаху дорівнює $190{ }^{\circ} \mathrm{C}$. Теплотворна здатність - 6870,83 кКал / кг [10].

У багатьох країнах реалізуються програми отримання рідких продуктів піролізу. Створені промислові установки, в тому числі: Малайзія, BTG, 50 т/ добу, сировина - відходи плодів кокоса; Ensyn (Канада), 100 т / добу. [10]. Однією 3 провідних компаній з виробництва біонафти у світі є Dinamotive Energy Systems (Канада). За технологією компанії Dinamotive здійснюється виробництво таких видів продукції: біонафта марки BioOil (60-75\% мас.), деревне вугілля (15$20 \%$ мас.), несконденсовані гази (10-20\% мас.), а також біонафта марки BioOil Plus [2].

В канадській провінції Онтаріо працює підприємство, яке переробляє за добу 200 т найрізноманітнішої сировини (деревину, солому, кукурудзяні відходи, ТПВ та ін.). 31 т відходів виходить 600-800 кг біонафти.

Одним із прикладів промислового отримання біонафти є перспективний процес, 
розроблений фахівцями компанії Changing World Technologies Inc. Технологія полягає в отриманні біонафти й газу 3 відходів деревообробної промисловості, сільського господарства, біологічних залишків, каналізаційних стоків, важких нафтопродуктів та ін. [2].

У 2015 році почала промисловий випуск біонафти компанія UPM (Фінляндія). Підприємство 3 виробництва інноваційного продукту розташоване на території целюлознопаперового підприємства Kaukas. Продукт виробляється шляхом переробки відходів сировини, що надходить 3 заводів групи UPM. Технологія виробництва грунтується на власних розробках компанії. Щорічний випуск біонафти сягає приблизно 120 млн. літрів [11]. Використання нової технології має позитивний екологічний ефект, оскільки використання отриманого біодизельного палива знижує викиди парникових газів в атмосферу на $80 \%$ в порівнянні з традиційним дизелем.

Німецька компанія ITC Solution AG розробила технологію Biooil (в перекладі «біонафта»), яка була презентована президентом компанії Гюнтером Краузе на екологічному форумі «Green mind» у Києві. У Німеччині ця технологія застосовується вже 2 роки. Технологія здатна переробляти побутові та промислові відходи в нафту, яка за своїми властивостями перевершує природну сиру нафту. Крім біосировини на установці Biooil можна переробляти як нафтопромислові, так і міські відходи, а також пластмаси, шлами тощо.

В Україні промислове виробництво біонафти ще не розвинене, але ведуться як теоретичні, так і експериментальні розробки в цьому напрямі. В Інституті технічної теплофізики НАН України (м. Київ, Україна) було проведено експериментальні дослідження процесу швидкого піролізу біомаси 3 метою визначення можливості отримання біонафти 3 деревної тріски, а також проведено порівняльний аналіз отриманої біонафти 3 аналогом, що був отриманий в лабораторії університету у Флоренції [12]. В якості робочої сировини використовувалася деревна тріска розміром від 0,5 до 5 мм, вологість якої становила $4 \%$ від маси. Експеримент проводився за допомогою абляційного реактора шнекового типу. В ході експерименту вдалося досягти безперервного виходу біонафти на рівні до $50 \%$ від маси вихідної сировини з вищою теплотою згоряння 16 мДж/кг. За даними хімічного аналізу вміст сірки в отриманії біонафти склав усього $0,03 \%$. Цей факт підтверджує відомості, викладені в роботі [6]. В результаті порівняльного аналізу зразка біонафти 3 іноземним аналогом було встановлено, що він не поступається за своїми основними характеристиками біонафті, що була отримана в лабораторії університету Флоренції. Так, вміст сірки в іноземному аналозі склав 0,02$0,05 \%$, а вища теплота згоряння 16-19 мДж / кг [12], що не набагато відрізняється від аналогічних показників біонафти, отриманої в лабораторії Інституту технічної теплофізики НАН України. Все це говорить про те, що в Україні є перспективи в галузі виробництва та використання цього екологічно чистого виду біопалива.

Виробництво й застосування рідких продуктів піролізу в Україні може мати істотний соціально-економічний та екологічний ефект i знизити залежність країни від поставок дорогих імпортних енергоносіїв. Хоча наявність відновлюваних ресурсів в окремих регіонах України не завжди свідчить про економічну доцільність їх використання, проте в цілому перехід 3 нафтопродуктів на відновлювані види рідкого палива може дозволити отримати економію за рахунок скорочення витрат на традиційне паливо. При цьому кожен випадок заміни традиційних нафтопродуктів продуктами швидкого піролізу лігноцелюлозної біомаси потрібно розглядати окремо, враховуючи цілий комплекс різноманітних факторів.

Висновок. На основі аналізу сучасного стану розвитку промислового виробництва біонафти методом швидкого піролізу рослинної сировини, встановлено, що технологія виробництва біонафти з лігноцелюлозної біомаси має широке поширення в багатьох країнах світу, що дає можливість авторам роботи стверджувати, що цей напрямок $є$ перспективним для розвитку, як в світі, так і в Україні. У зв'язку 3 цим необхідно вести подальші теоретичні та експериментальні розробки. 
1. Хутская Н.Г.,

Пальчёнок Г.И. Энергосберегающие технологии термической конверсии биомассы и лигнокарбонатных отходов. Минск. БНТУ. 2015. 53 с.

2. Р Рахманкулов Д.Л., Николаева C.B., Денисов С.B. Успехи и проблемы производства альтернативных источников топлива и химического сырья. Пиролиз биомассы. Башкирский химический журнал. 2008. № 2(15). С. 36-52.

3. Ролдугина Е.A. Гидрооблагораживание бионефти и ее компонентов на гетерогенных катализаторах, содержащих благородные металлы: автореф. дис. на соискание учен. степени канд. хим. наук: спец. 02.02.13. М. 2019. 23 с.

4. Виды биотоплив и технологии их производства. [Електронний ресурс]. URL: http://www.metallurgist.pro/tehnologii-polucheniya-iprimeneniya-piroliznogo-biotopliva (дата звернення: 10.07.2019)

5. Bridgwater A.V. Review of fast Pyrolysis of Biomass and Product Upgrading. Biomass and Bioenergy. 2011, Vol. 38. Pp. 68-94. https://doi.org/10.1016/j.biombioe.2011.01.048.

6. Железная Т.А., Гелетуха Г.Г. Современные технологии получения жидкого топлива из биомассы быстрым пиролизом. Часть 2. Промышленная теплотехника. 2005. № 5(27). С. 79-90.

7. Гафуров Н.М., Хисматуллин Р.Ф. Особенности технологии быстрого пиролиза биомассы. Инновационная наука. 2016. № 5(17). С. $65-$ 66.

8. Зубенко В.И. Технологія швидкого піролізу біомаси в абляційному реакторі шнекового типу: автореф. дис. на здобуття наук. ступеня канд. техн. наук: спец. 05.14.08. К. 2018. 23 с.

9. Грачев А.Н., Башкиров В.Н., В Валеев И.А., Хисматов Р.Г. Макаров А.А., Тунщев Д.В. Технология быстрого пиролиза при энергетическом использовании низкокачественной древесины. Энергетика Татарстана. 2008. № 4. С. 16-21.

10. Василевич С. В., Малько М. В., Асадчий А.Н., Дегтеров Д.В. Разработка экспериментального стенда для получения жидких продуктов пиролиза путем термохимической конверсии биомассы. Вестник ГГТУ им. П.О. Сухого. 2019. № 1. С. 64-69.

11. Грачев А.Н. Мобильная установка термохимической конверсии биомассы и других органических отходов с получением жидких органических продуктов и мелкодисперсного угля. тези доповідей. Міжнародна науково-практична конференція «Энергия из биомассы: котельные и ТЭЦ на биотопливе, производство пеллет, брикетов, биогаза в России». М. 8 червня 2017 р. 4 с.

12. Клименко В.М., Баштовий А.І., Зубенко В.I., Антошук T.O. Дослідження швидкого піролізу біомаси в абляційному шнековому реакторі.
Промислова теплотехніка. 2016. № 2(38). С. 48-55. https://doi.org/10.31472/ihe.2.2016.06.

\section{REFERENCES}

1. Khutskaya N.G., Palchonok G.I. Energosberegayushchiye tekhnologyy termicheskoy konversii biomassyi i lignokarbonatnykh otkhodov. [Energy-saving technologies for thermal conversion of biomass and lignocarbonate waste]. Minsk. BNTU. 2015. 53 p. [in Russian].

2. Rahmankulov D.L., Vildanov F.Sh., Nikolaeva S.V., Denisov S.V. Uspehi i problemyi proizvodstva al'ternativnyh istochnikov topliva i himicheskogo syr'ya. Piroliz biomassyi. [Successes and challenges in the production of alternative sources of fuel and chemical raw materials. Biomass pyrolysis]. Bashkirskiy himicheskiy zhurnal. 2008. No. 2(15). Pp. 36-52. [in Russian].

3. Roldugina E.A. Gidrooblagorazhivanie bionefti i ee komponentov na geterogennyih katalizatorah, soderzhaschih blagorodnyie metally. [Hydrofinishing of bio-oil and its components on heterogeneous catalysts containing precious metals]. avtoref. dys. na soiskanie uchen. stepeni kand. khim. nauk. spets. 02.02.13. Moskva. 2019. 23 p. [in Russian].

4. Vidy byotopliv i tekhnologyy ih proizvodstva. [Types of biofuels and technologists for their production]. [Elektronic resource]. URL: http://www.metallurgist.pro/tehnologii-polucheniya-iprimeneniya-piroliznogo-biotopliva (Applying date: 10.07.2020). [in Russian].

5. Bridgwater A.V. Review of fast Pyrolysis of Biomass and Product Upgrading. Biomass and Bioenergy. 2011, Vol. 38. Pp. 68-94. https://doi.org/10.1016/j.biombioe.2011.01.048. [in English].

6. Zheleznaya T.A., Geletuha G.G. Sovremennye tekhnologyy polucheniya zhidkogo topliva iz biomassyi bystrym pirolizom. Ch. 2. [Modern technologies for producing liquid fuel from biomass by fast pyrolysis. Part 2]. Promyishlennaya teplotehnika. 2005. No 5(27). Pp. 7990. [in Russian].

7. Gafurov N.M. Khismatullin R.F. Osobennosti tekhnologyy bystrogo piroliza biomassyi. [Features of the technology of fast pyrolysis of biomass]. Innovatsionnaya nauka. 2016. No 5 (17). Pp. 65-66 [in Russian].

8. Zubenko V.I. Tekhnolohiya shvydkoho pirolizu biomasy $\mathrm{v}$ ablyatsiynomu reaktori shnekovoho typu. [Technology of rapid pyrolysis of biomass in a screw-type ablation reactor]. avtoref. dys. na zdobuttya nauk. stupenya kand. tekhn. nauk: spets. 05.14.08. K. 2018. 23 p. [in Ukrainian].

9. Grachev A.N., Bashkirov V.N., Valeyev I.A., Khismatov R.G. Makarov A.A., Tuntsev D.V. Tekhnologiya bystrogo piroliza pri energeticheskom 
ispolzovanii nizkokachestvennoy drevesiny. [Technology of rapid pyrolysis in the energy use of low-quality wood]. Energetika Tatarstana. 2008. No 4. Pp. 16-21. [in Russian].

10. Vasilevich S. V., Mal'ko M. V., Asadchy A. N., Degterov D. $V$. Razrabotka eksperimental'nogo stenda dlya polucheniya zhidkikh produktov piroliza putem termokhimicheskoy konversii biomassyi. [Development of an experimental bench for the production of liquid pyrolysis products by thermochemical conversion of biomass]. Vestnik GGTU im. P.O. Sukhogo. 2019. No.1. Pp. 64-69. [in Russian].

11. Grachev A.N. Mobil'naya ustanovka termokhimicheskoy konversii biomassyi i drugikh organicheskikh otkhodov $\mathrm{s}$ polucheniyem zhidkikh organicheskikh produktov i melkodispersnogo uglya.
[Mobile plant for the thermochemical conversion of biomass and other organic waste to produce liquid organic products and fine coal]. Tezy dopovidey. Mizhnarodna naukovo-praktychna konferentsiya «Energiya iz biomassyi: kotel'nyye i TETS na biotoplive, proizvodstvo pellet, briketov, biogaza v Rossii». [Energy from biomass: boiler houses and thermal power plants on biofuel, production of pellets, briquettes, biogas in Russia]. M. 8 June 2017 year. P. 4. [in Russian].

12. Klymenko V.M., Bashtovyy A.I., Zubenko V.I., Antoshchuk T.O. Doslidzhennya shvydkoho pirolizu biomasy v ablyatsiynomu shnekovomu reaktori. [Investigation of rapid pyrolysis of biomass in an ablation screw reactor]. Promyslova teplotehnika. 2016. No 2 (38). Pp. 48-55. [in Ukrainian].

DOI: https://doi.org/10.31472/ihe.2.2016.06.

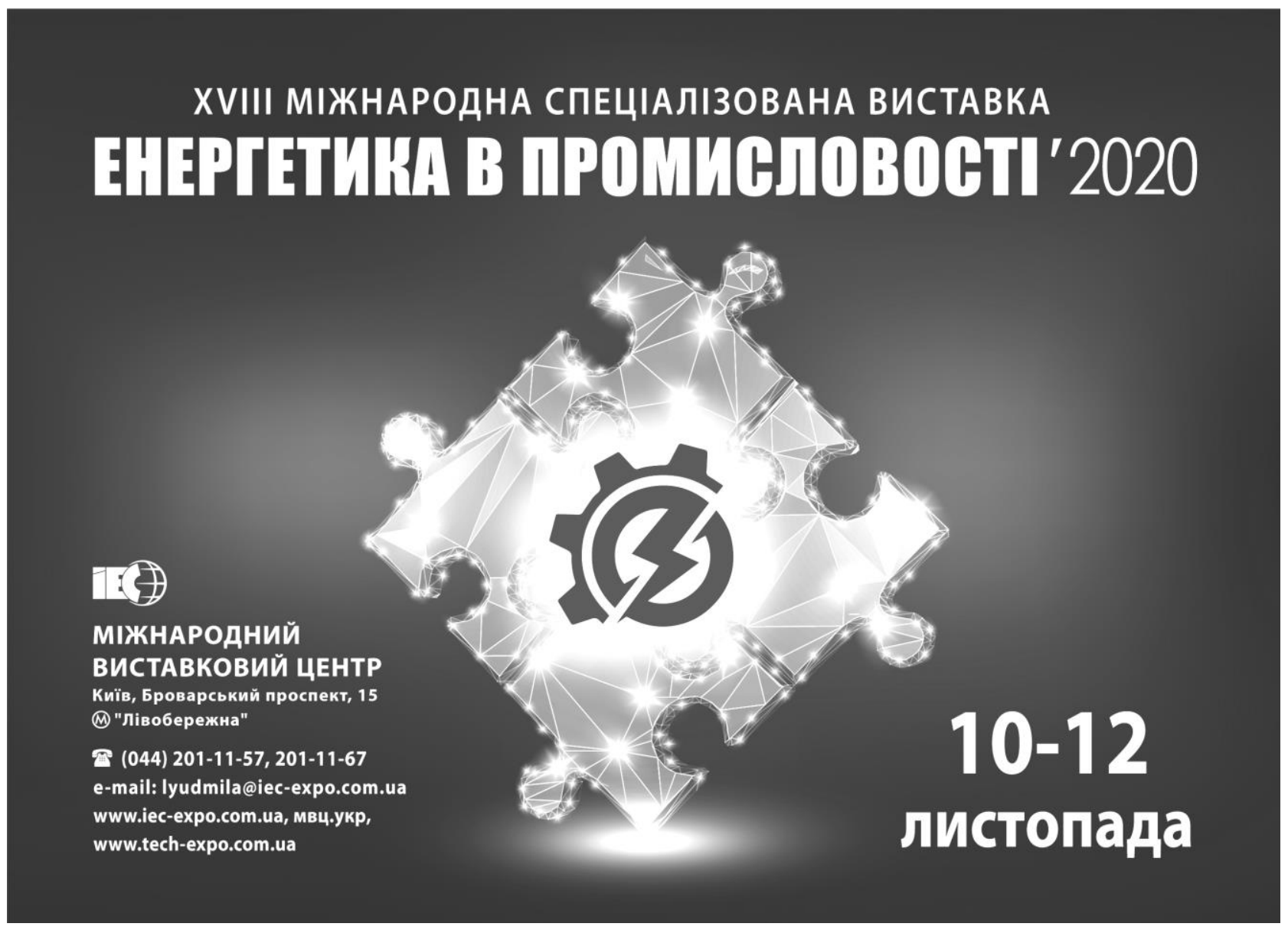

